\title{
Effect of 3-nitrooxypropanol on methane and hydrogen emissions, methane isotopic signature, and ruminal fermentation in dairy cows
}

\author{
J. C. Lopes, ${ }^{*}$ L. F. de Matos, ${ }^{*}$ M. T. Harper, ${ }^{*}$ F. Giallongo, ${ }^{*}$ J. Oh, ${ }^{*}$ D. Gruen,† S. Ono,† M. Kindermann,‡ \\ S. Duval, $\S$ and A. N. Hristov*1 \\ *Department of Animal Science, The Pennsylvania State University, University Park 16802 \\ †Department of Earth, Atmospheric and Planetary Sciences, Massachusetts Institute of Technology, Cambridge 02139 \\ fDSM Nutritional Products, Animal Nutrition and Health, Basel, Switzerland CH-4002 \\ §DSM Nutritional Products France, Research Centre for Animal Nutrition and Health, Saint Louis Cedex, France 68305
}

\section{ABSTRACT}

The objective of this crossover experiment was to investigate the effect of a methane inhibitor, 3-nitrooxypropanol (3NOP), on enteric methane emission, methane isotopic composition, and rumen fermentation and microbial profile in lactating dairy cows. The experiment involved 6 ruminally cannulated late-lactation Holstein cows assigned to 2 treatments: control and $3 \mathrm{NOP}(60 \mathrm{mg} / \mathrm{kg}$ of feed dry matter). Compared with the control, 3NOP decreased methane emission by $31 \%$ and increased hydrogen emission from undetectable to $1.33 \mathrm{~g} / \mathrm{d}$. Methane emissions per kilogram of dry matter intake and milk yield were also decreased $34 \%$ by 3 NOP. Milk production and composition were not affected by $3 \mathrm{NOP}$, except milk fat concentration was increased compared with the control. Concentrations of total VFA and propionate in ruminal fluid were not affected by treatment, but acetate concentration tended to be lower and acetate-to-propionate ratio was lower for 3NOP compared with the control. The 3NOP decreased the molar proportion of acetate and increase those of propionate, butyrate, valerate, and isovalerate. Deuterium-to-hydrogen ratios of methane and the abundance of ${ }^{13} \mathrm{CH}_{3} \mathrm{D}$ were similar between treatments. Compared with the control, minor $(4 \%)$ depletion in the ${ }^{13} \mathrm{C} /{ }^{12} \mathrm{C}$ ratio was observed for $3 \mathrm{NOP}$. Genus composition of methanogenic archaea (Methanobrevibacter, Methanosphaera, and Methanomicrobium) was not affected by 3NOP, but the proportion of methanogens in the total cell counts tended to be decreased by 3NOP. Prevotella spp., the predominant bacterial genus in ruminal contents in this experiment, was also not affected by 3 NOP. Compared with the control, Ruminococcus and Clostridium spp. were decreased and Butyrivibrio spp. was increased by 3 NOP. This experiment demon-

\footnotetext{
Received December 28, 2015.

Accepted March 8, 2016.

${ }^{1}$ Corresponding author: anh13@psu.edu
}

strated that a substantial inhibition of enteric methane emission by $3 \mathrm{NOP}$ in dairy cows was accompanied with increased hydrogen emission and decreased acetate-topropionate ratio; however, neither an effect on rumen archaeal community composition nor a significant change in the isotope composition of methane was observed.

Key words: methane, 3-nitrooxypropanol, rumen fermentation, dairy cow

\section{INTRODUCTION}

In the rumen, $\mathrm{CH}_{4}$ is an end product of microbial fermentation of carbohydrates and AA. Methanogenesis is the major sink for hydrogen in the rumen, but enteric $\mathrm{CH}_{4}$ represents also a net feed energy loss for the animal (Johnson and Johnson, 1995) and is a major contributor to agricultural greenhouse gas (GHG) emissions globally (IPCC, 2014).

Several reviews presented technical options for abatement of livestock GHG emissions (Boadi et al., 2004; McAllister and Newbold, 2008; Hristov et al., 2013). These strategies focus on feeding management practices such as fat supplementation, concentrate inclusion, processing low-quality feeds, and improving overall forage quality, as well as feed additives, such as alternative electron receptors, ionophoric antibiotics, plant bioactive compounds, enzymes, and $\mathrm{CH}_{4}$ inhibitors.

Among $\mathrm{CH}_{4}$ inhibitors, bromochloromethane, 2-bromo-ethane sulfonate, and chloroform are the most studied compounds in ruminants (Hristov et al., 2013). Both in vitro and in vivo experiments have demonstrated that these compounds were effective in reducing $\mathrm{CH}_{4}$ emission without negatively affecting animal productivity (Sawyer et al., 1974; Goel et al., 2009; Tomkins et al., 2009; Abecia et al., 2012). Use of these compounds, however, is limited due to toxicity, rumen adaptation, or environmental regulation issues (Hristov et al., 2013). In response, natural or synthetic compounds with a similar mode of action are being 
developed. The compound tested in this experiment, 3-nitrooxypropanol (3NOP), was designed to inhibit the activity of methyl coenzyme-M reductase (Duval and Kindermann, 2012), the enzyme responsible for microbial formation of $\mathrm{CH}_{4}$ (Ermler et al., 1997). Recent studies showed that $3 \mathrm{NOP}$ consistently decreased enteric $\mathrm{CH}_{4}$ emission in lactating dairy cows (Haisan et al., 2014; Reynolds et al., 2014). In a 12-wk study, Hristov et al. (2015a) reported persistent reduction of enteric $\mathrm{CH}_{4}$ emission, whereas productive performance of high-producing dairy cows was not affected by $3 \mathrm{NOP}$ supplementation. In their study, however, the effect of 3 NOP on ruminal fermentation could not be evaluated because the cows used were not ruminally cannulated.

Stable isotope compositions of $\mathrm{CH}_{4}\left({ }^{13} \mathrm{C} /{ }^{12} \mathrm{C}, \mathrm{D} / \mathrm{H}\right.$, and ${ }^{13} \mathrm{CH}_{3} \mathrm{D}$, where $\mathrm{D}$ is a stable isotope of hydrogen with one extra neutron) reflect the isotope compositions of substrate $\left({ }^{13} \mathrm{C} /{ }^{12} \mathrm{C}\right.$ of feeds and $\mathrm{D} / \mathrm{H}$ of rumen fluids), as well as isotope fractionation associated with microbial methanogenesis. The latter is shown to be a function of pathways, growth phase, and hydrogen levels (Whiticar et al., 1986; Burke, 1993; Valentine et al., 2004; Wang et al., 2015). For the $\mathrm{CO}_{2}$ reduction pathway, thought to be dominant in the rumen (Hungate, 1966), large ${ }^{13} \mathrm{C}$-depletion is associated with stationary growth, low metabolic rates, and low $\mathrm{H}_{2}$ levels, whereas large $\mathrm{D}$-depletion is associated with high metabolic rate and high $\mathrm{H}_{2}$ levels (Burke, 1993; Zyakun, 1996; Valentine et al., 2004; Wang et al., 2015).

Therefore, one of the objectives of our study was to test if, in addition to decreased $\mathrm{CH}_{4}$ emission, $3 \mathrm{NOP}$ affects $\mathrm{CH}_{4}$ isotope compositions due to changes in physiology or environmental conditions for methanogenesis in lactating dairy cows. The study also investigated the effect of 3NOP on rumen fermentation, ruminal microbial profile, and production variables. We hypothesized that $3 \mathrm{NOP}$ would, similar to previous experiments, decrease acetate-to-propionate ratio in ruminal fluid and, due to the large reduction in $\mathrm{CH}_{4}$ emission, would also affect the composition of ruminal archaea and the isotopic signature of enteric $\mathrm{CH}_{4}$.

\section{MATERIALS AND METHODS}

Animals involved in these experiments were cared for according to the guidelines of the Pennsylvania State University Animal Care and Use Committee. The committee reviewed and approved the experiment and all procedures carried out in this study.

\section{Animals and Experimental Design}

The experiment used 6 ruminally cannulated latelactation Holstein cows in a $2 \times 2$ crossover design with
2 experimental periods of $14 \mathrm{~d}$ each. A 7-d washout period was allowed between the experimental periods. Cows were grouped by DIM and current milk yield in 2 squares of 3 cows each. Cows were $1.3(\mathrm{SD}=0.52)$ lactations, $233(\mathrm{SD}=45)$ DIM at the beginning of the experiment, had an average BW during the experiment of $610(\mathrm{SD}=158) \mathrm{kg}$, and were fitted with soft plastic ruminal cannulas $(10.2 \mathrm{~cm}$ internal diameter; Bar Diamond Inc., Parma, ID). Within a period, the first $10 \mathrm{~d}$ served as adaptation and the remaining $4 \mathrm{~d}$ were used for sample and production data collection. Cows received recombinant bST (Posilac, Elanco Co., Greenfield, IN; $500 \mathrm{mg} / \mathrm{cow}$, i.m.) on d 1 of each experimental period. The following 2 treatments were tested: $0 \mathrm{mg}$ of $3 \mathrm{NOP} / \mathrm{kg}$ of dietary DM (control) and $60 \mathrm{mg}$ of $3 \mathrm{NOP} / \mathrm{kg}$ of DM (3NOP; DSM Nutritional Products, Basel, Switzerland). The $60-\mathrm{mg} / \mathrm{kg}$ of DM dose was selected based on a previous experiment with 3NOP (Hristov et al., 2015a). The basal diet was formulated to meet or exceed the $\mathrm{NE}_{\mathrm{L}}$ and $\mathrm{MP}$ requirements of a Holstein cow (according to NRC, 2001) with $610 \mathrm{~kg}$ of BW, producing $32 \mathrm{~kg}$ of milk/d with $4.10 \%$ milk fat and $3.60 \%$ true milk protein, and consuming $24 \mathrm{~kg} / \mathrm{d}$ of DMI (Table 1). Diets were fed as TMR once daily at $0800 \mathrm{~h}$ targeting $10 \%$ refusals. The $3 \mathrm{NOP}$ supplement contained $8.85 \% 3 \mathrm{NOP}$ on $\mathrm{SiO}_{2}$ and propylene glycol; the placebo supplement contained $\mathrm{SiO}_{2}$ and propylene glycol only (Hristov et al., 2015a). The supplements were mixed with the TMR to deliver the final $3 \mathrm{NOP}$ concentration as indicated above. Cows were milked twice daily at approximately 0600 and $1800 \mathrm{~h}$ and had continuous access to a fresh water source.

\section{Sampling and Measurements}

During the experiment, TMR offered and refusals were recorded daily. Samples of the forages were collected once weekly and samples of the TMR were collected twice weekly. Samples of the concentrate feeds were collected once per experimental period. Feed samples were dried for $48 \mathrm{~h}$ at $65^{\circ} \mathrm{C}$ in a forced-air oven and ground in a Wiley Mill (Thomas Scientific, Swedesboro, NJ) through a 1-mm sieve for further analysis.

Composite (equal DM weight basis) samples of the forages and concentrate feeds fed during the experiment were submitted to Cumberland Valley Analytical Services (Maugansville, MD) for wet chemistry analyses of $\mathrm{CP}, \mathrm{NDF}, \mathrm{ADF}, \mathrm{Ca}, \mathrm{P}$, and estimated $\mathrm{NE}_{\mathrm{L}}$ (CVAS, 2014). The analyzed composition of the feed ingredients and their inclusion in the TMR was used to compute the $\mathrm{CP}, \mathrm{NDF}, \mathrm{ADF}, \mathrm{Ca}$, and $\mathrm{P}$ concentration of the diets (Table 1). During the last $3 \mathrm{~d}$ of each period, $\mathrm{CH}_{4}$, $\mathrm{CO}_{2}$, and $\mathrm{H}_{2}$ emission were measured using the GreenFeed system (C-Lock Inc., Rapid City, SD) 8 times in 
$3 \mathrm{~d}$ covering a $24-\mathrm{h}$ period at 0900,1500 , and $2100 \mathrm{~h}$ (sampling d 1), 0300, 1200, and $1700 \mathrm{~h}$ (sampling d 2), and 0000 and $0500 \mathrm{~h}$ (sampling d 3). Gas measurements were performed as described by Hristov et al. (2015b). A rumen cannula extension (fistula attachment; C-Lock Inc.) was used to capture and direct through GreenFeed rumen gas potentially leaking through the cannula. The cannula extension consisted on an impermeable fabric covering the back and sides of the cow with a tubing attached to it in close proximity of the rumen cannula and extending from the cannula to the GreenFeed

Table 1. Ingredient and chemical composition of the basal diet fed during the trial

\begin{tabular}{|c|c|}
\hline Item & Measurement \\
\hline \multicolumn{2}{|l|}{ Ingredient, $\%$ of DM } \\
\hline Corn silage $^{1}$ & 43.5 \\
\hline Alfalfa haylage $^{2}$ & 12.0 \\
\hline Soybean seeds, whole heated ${ }^{3}$ & 8.7 \\
\hline Canola meal $^{4}$ & 8.6 \\
\hline Corn grain, ground & 6.0 \\
\hline Candy by-product meal ${ }^{5}$ & 6.5 \\
\hline SoyPLUS ${ }^{6}$ & 5.0 \\
\hline Cottonseed, hulls & 3.2 \\
\hline Molasses $^{7}$ & 3.5 \\
\hline Vitamin and mineral premix ${ }^{8}$ & 3.0 \\
\hline \multicolumn{2}{|c|}{ Composition, $\%$ of DM (or as indicated) } \\
\hline $\mathrm{CP}^{g^{2}}$ & 16.1 \\
\hline $\mathrm{RDP}^{10}$ & 9.8 \\
\hline $\mathrm{RUP}^{10}$ & 6.9 \\
\hline $\mathrm{NDF}^{9}$ & 30.9 \\
\hline $\mathrm{ADF}^{9}$ & 23.2 \\
\hline $\mathrm{NE}_{\mathrm{L}}, \mathrm{Mcal} / \mathrm{kg}^{9}$ & 1.69 \\
\hline $\mathrm{Ca}^{9}$ & 1.02 \\
\hline $\mathrm{P}^{9}$ & 0.39 \\
\hline $\mathrm{NFC}^{10}$ & 45.2 \\
\hline
\end{tabular}

${ }^{1}$ Corn silage was $46.5 \% \mathrm{DM}$ and contained (DM basis) $6.7 \% \mathrm{CP}, 32.4 \%$ $\mathrm{NDF}$, and $42.7 \%$ starch.

${ }^{2}$ Alfalfa haylage was $90.7 \% \mathrm{DM}$ and contained (DM basis) $21.0 \% \mathrm{CP}$, and $43.7 \%$ NDF.

${ }^{3}$ Soybean seeds contained (DM basis) $40.0 \% \mathrm{CP}$.

${ }^{4}$ Canola meal contained (DM basis) $40.9 \% \mathrm{CP}$.

${ }^{5}$ Candy by-product meal (Graybill Processing, Elizabethtown, PA) contained (DM basis) $16.9 \% \mathrm{CP}$ and $26.7 \% \mathrm{NDF}$.

${ }^{6}$ SoyPLUS (West Central Cooperative, Ralston, IA) contained (DM basis) $47.2 \% \mathrm{CP}$.

${ }^{7}$ Molasses (Westway Feed Products, Tomball, TX) contained (DM basis) $3.9 \% \mathrm{CP}$ and $66 \%$ total sugar.

${ }^{8}$ The premix (Cargill Animal Nutrition, Cargill Inc., Roaring Spring, $\mathrm{PA})$ contained (\%, as-is basis) trace mineral mix, $0.86 ; \mathrm{MgO}(56 \%$ $\mathrm{Mg}$ ), 8.0; $\mathrm{NaCl}, 6.4$; vitamin ADE premix (Cargill Animal Nutrition, Cargill Inc.), 0.48; limestone, 37.2; selenium premix (Cargill Animal Nutrition, Cargill Inc.), 0.07; and dry corn distillers grains with solubles; 46.7. Ca, 14.1\%; P, 0.39\%; Mg, 4.59\%; K, 0.44\%; S, 0.39\%; Se, $6.91 \mathrm{mg} / \mathrm{kg} ; \mathrm{Cu}, 362 \mathrm{mg} / \mathrm{kg}$; Zn, 1,085 mg/kg; Fe, $186 \mathrm{mg} / \mathrm{kg}$, vitamin A, 276,717 IU/kg; vitamin D, 75,000 IU/kg; and vitamin E, 1,983 IU/ $\mathrm{kg}$.

${ }^{9}$ Values were calculated using the chemical analysis (Cumberland Valley Analytical Services Inc., Maugansville, MD) of the ingredients of the diet.

${ }^{10}$ Estimated by NRC (2001). unit. The tubing was attached to a port that directed the collected gas toward GreenFeed sensors. Constant negative pressure was maintained by using a vacuum pump to withdraw gas from between the fabric sheet and the animal into the tubing. The gas was then routed from the tubing and released into the GreenFeed air collection pipe where total airflow and concentrations of $\mathrm{CH}_{4}, \mathrm{CO}_{2}$, and $\mathrm{H}_{2}$ were continuously measured.

Separate spot rumen gas samples were collected during experimental period 2 through the rumen cannula using a sampling device described in Tekippe et al. (2011). Samples were collected once on d 13, between 3 and $4 \mathrm{~h}$ after feeding, in 250-mL Kimax glass serum bottles (Kimble Chase, Vineland, NJ) sealed with blue chlorobutyl stoppers (Bellco, Vineland, NJ) and stored at room temperature until analyzed for isotopic composition of $\mathrm{CH}_{4}$ (Ono et al., 2014). Methane was extracted from rumen gas samples using preparatory gas chromatography system equipped with a packed column (Carboxen-1000, $152 \mathrm{~cm}$ length, $3.2 \mathrm{~mm}$ o.d.) at $30^{\circ} \mathrm{C}$ (Wang et al., 2015). Isotopologue ratios of purified $\mathrm{CH}_{4}$ samples were measured using tunable infrared direct absorption spectroscopy. Tunable infrared direct absorption spectroscopy measures isotopologue specific absorption in the mid-infrared ( $8.5 \mu \mathrm{m}$ wavelength) region (corresponding $\mathrm{C}-\mathrm{H}$ and $\mathrm{C}-\mathrm{D}$ bending vibrations) using multipass (76 m pathlength) direct absorption cell and continuous wavelength quantum cascade lasers (Ono et al., 2014).

Isotope ratios are reported in conventional delta notations:

$$
\begin{aligned}
\delta^{13} \mathrm{C} & =\frac{\left({ }^{13} \mathrm{C} \div{ }^{12} \mathrm{C}\right)_{\text {sample }}}{\left({ }^{13} \mathrm{C} \div{ }^{12} \mathrm{C}\right)_{\text {PDB }}}-1, \\
\delta \mathrm{D} & =\frac{(\mathrm{D} \div \mathrm{H})_{\text {sample }}}{(\mathrm{D} \div \mathrm{H})_{\text {SMOW }}}-1,
\end{aligned}
$$

where PDB and SMOW refer to the reference ratios, Pee Dee Belemnite and Standard Mean Ocean Water, respectively. The clumped isotopologue abundance is reported as $\Delta^{13} \mathrm{CH}_{3} \mathrm{D}$, which represents the deviation from a random (stochastic) distribution (Ono et al., 2014):

$$
\Delta^{13} \mathrm{CH}_{3} \mathrm{D}=\left[{ }^{13} \mathrm{CH}_{3} \mathrm{D}\right]\left[{ }^{12} \mathrm{CH}_{4}\right] \div\left[{ }^{13} \mathrm{CH}_{4}\right]\left[{ }^{12} \mathrm{CH}_{3} \mathrm{D}\right]-1 .
$$

At the time of gas collection, a sample of rumen fluid was collected from the ventral rumen, filtered through 4 layers of cheesecloth, transferred into $20-\mathrm{mL}$ scintillation vials (Fisher Scientific, Pittsburgh, PA), and stored 
at $4^{\circ} \mathrm{C}$ until analyzed for dissolved $\mathrm{H}_{2}$ (Vaportech Services, Valencia, PA) according to Chapelle et al. (1997).

Rumen fluid and whole rumen contents samples were collected (as described in Hristov et al., 2011) on d 14 of each experimental period at 0 (before feeding), 2, 4, 6, and $8 \mathrm{~h}$ after feeding. Rumen fluid $\mathrm{pH}$ was analyzed immediately (pH meter 59000-60 pH Tester, Cole-Parmer Instrument Company, Vernon Hills, IL) and samples were further processed for analyses of ammonia and VFA (Hristov et al., 2011). Aliquots of the whole rumen contents were composited on an equal wet weight basis per cow and period and frozen immediately at $-80^{\circ} \mathrm{C}$ for analysis of bacterial and archaeal order and genus distribution according to Oh et al. (2015). Briefly, DNA was extracted from $300 \mathrm{mg}$ of material using the MO BIO Powersoil kit (MO BIO Laboratories Inc., Carlsbad, CA) following the manufacturer's instructions. The 16S rRNA gene standard V4 variable region PCR primers 515/806 were used in a single-step 30-cycle PCR using the HotStarTaq Plus Master Mix Kit (Qiagen Inc., Valencia, CA) under the following conditions: $94^{\circ} \mathrm{C}$ for $3 \mathrm{~min}$, followed by 28 cycles ( 5 cycles used on PCR products) of $94^{\circ} \mathrm{C}$ for $30 \mathrm{~s}, 53^{\circ} \mathrm{C}$ for $40 \mathrm{~s}$, and $72^{\circ} \mathrm{C}$ for $1 \mathrm{~min}$, after which a final elongation step at $72^{\circ} \mathrm{C}$ for 5 min was performed. Sequencing was performed at MR DNA (www.mrdnalab.com, Shallowater, TX) on an Ion Torrent PGM (Thermo Fisher Scientific Inc., Waltham, MA) following the manufacturer's guidelines. Bacterial quantification was performed using quantitative PCR based on a universal primer, as indicated above. A linear standard was used to calculate the estimated cell counts. Sequence data were processed using a standard taxonomic analysis pipeline (MR DNA). In short, sequences were depleted of barcodes and primers, then sequences $<150 \mathrm{bp}$ were removed and sequences with ambiguous base calls and with homopolymer runs exceeding 6 bp were also removed. Sequences were denoised and chimeras removed. Operational taxonomic units were defined by clustering at $3 \%$ divergence $(97 \%$ similarity). Final operational taxonomic units were taxonomically classified using BLASTn against a database derived from RDPII (http://rdp.cme.msu.edu) and NCBI (www.ncbi.nlm.nih.gov).

Milk samples were collected at 2 consecutive milkings (evening and morning) in the last day of each experimental period. Samples were preserved with 2-bromo2-nitropropane-1,3-diol and submitted for analysis of milk fat, true protein, lactose, and MUN (Dairy One, Ithaca, NY) using infrared spectroscopy (MilkoScan 4000, Foss Electric, Hillerød, Denmark). Morning and evening samples were analyzed separately so milk component concentration and yield could be weighed for morning and evening milk yields.

\section{Statistical Analysis}

All data were analyzed using the MIXED procedure of SAS (version 9.4, SAS Institute Inc., Cary, NC). The statistical model included treatment, experimental period, and treatment $\times$ period interaction. Square and cow within square were random effects and all others were fixed. Milk yield and DMI data for the last $4 \mathrm{~d}$ of each experimental period were averaged and the average values were used in the statistical analysis. Data for one cow in period 2 (control) were removed from the analysis due to low milk production (64\% of her milk production in period 1 and $43 \%$ of the average milk production for all cows in period 2). Rumen gas emissions and fermentation data (except dissolved $\mathrm{H}_{2}$ ) were analyzed as repeated measures. The model included treatment, experimental period, time of sampling, and treatment $\times$ period and treatment $\times$ time of sampling interactions. Means were separated by pairwise $t$-test (pdiff option of PROC MIXED). Statistical differences were considered significant at $P \leq 0.05$ and a trend at $0.05<P \leq 0.10$. Data in tables are presented as least squares means.

\section{RESULTS AND DISCUSSION}

Carbon dioxide emission was not affected by treatment, although we noted a numerical increase $(P=$ 0.15 ) by about $4 \%$ for 3 NOP (Table 2 ). Methane emission was decreased by $31 \%(P<0.001)$, whereas $\mathrm{H}_{2}$ emission increased substantially $(P<0.001)$ for $3 \mathrm{NOP}$ compared with the control. When expressed per unit of DMI or milk yield, $\mathrm{CH}_{4}$ emission was, on average, about $34 \%$ lower $(P<0.001)$ for $3 \mathrm{NOP}$ compared with the control. These results are in agreement with our data from a larger production experiment where $3 \mathrm{NOP}$ decreased $\mathrm{CH}_{4}$ emission in dairy cows by an average of $29 \%$ (Hristov et al., 2015a). Similar results, although of a different magnitude, were also reported for 3NOP by Reynolds et al. (2014) and Haisan et al. (2014). Reynolds et al. (2014) observed a reduction of 7 and $10 \%$ with the supplementation of 500 and $2,500 \mathrm{mg} / \mathrm{d}$ of $3 \mathrm{NOP}$, respectively, when $3 \mathrm{NOP}$ was dosed directly into the rumen of lactating dairy cows fed diets containing $60 \%$ forage. Haisan et al. (2014) reported a $64 \%$ reduction in $\mathrm{CH}_{4}$ emission in midlactating dairy cows supplemented with $2,500 \mathrm{mg} / \mathrm{d}$ of $3 \mathrm{NOP}$ top-dressed and fed a diet containing $38 \%$ forage. Studies testing $3 \mathrm{NOP}$ in beef cattle have also shown significant reduction in enteric $\mathrm{CH}_{4}$ emission. In a short-term experiment with beef heifers, Romero-Pérez et al. (2014) reported $\mathrm{CH}_{4}$ production was linearly decreased by 4 , 13 , and $38 \%$, for heifers receiving $0.75,2.25$, and 4.5 
$\mathrm{mg}$ of $3 \mathrm{NOP} / \mathrm{kg}$ of $\mathrm{BW}$ (or 412, 1,235, and 2,470 mg/ head per day), respectively. In a more recent long-term study (146 d) by the same group, 3NOP consistently decreased $\mathrm{CH}_{4}$ emission by $59 \%$ through the experiment (Romero-Pérez et al., 2015a). It has been reported that method of delivery of 3NOP (direct rumen administration, top-dressed, or mixed with the diet) and animal type (beef, dairy, sheep) can influence $\mathrm{CH}_{4}$ emission response (Romero-Pérez et al., 2014). Haisan et al. (2014) suggested that $\mathrm{CH}_{4}$ emission response to $3 \mathrm{NOP}$ may be diet-dependent, with enhanced mitigation potential when cows are fed low-forage diets.

Methanogenesis is the primary pathway to remove excess of $\mathrm{H}_{2}$ in the rumen, whereas propionate production is a competing alternative $\mathrm{H}_{2}$ sink (Hungate, 1967; Moss et al., 2000). The increase in $\mathrm{H}_{2}$ emissions by $3 \mathrm{NOP}$ was large, from undetectable in the control to $1.3 \mathrm{~g} / \mathrm{d}$, and similar to the results from our larger experiment (Hristov et al., 2015a). As pointed out by Hristov et al. (2015a), $\mathrm{H}_{2}$ emitted from the rumen was only a fraction of the estimated $\mathrm{H}_{2}$ available from the decrease in $\mathrm{CH}_{4}$ production due to $3 \mathrm{NOP}$. Increased concentration of dissolved $\mathrm{H}_{2}$ (see following discussion), possible adaptation of the rumen ecosystem, decreased $\mathrm{H}_{2}$ production, or redirection to alternative $\mathrm{H}_{2}$ sinks (Ungerfeld, 2015) may be possible mechanisms to explain the fate of the excess $\mathrm{H}_{2}$ resulting from 3NOP application.

Treatment had no effect on rumen $\mathrm{pH}$, total VFA, propionate, isobutyrate, and valerate concentrations (Table 3). There was no treatment $\times$ time of sampling interaction $(P \geq 0.41)$ for the fermentation variables, except for isobutyrate and isovalerate concentrations $(P=0.01)$. Examination of the data, however, showed no apparent trends in the concentration of isobutyrate across sampling points and the concentration of isovalerate was higher for $3 \mathrm{NOP}$ than the control for all sampling times. Supplementation of $3 \mathrm{NOP}$ tended to decrease $(P=0.08)$ the concentration of acetate and to increase $(P=0.08)$ that of butyrate. The concentration of isovalerate was increased $(P<0.01)$, and acetate-topropionate ratio was decreased $(P<0.01)$ by 3 NOP. The molar proportion of acetate was decreased $(P<$ 0.001 ) and those of propionate, butyrate, valerate, and isovalerate were increased $(P \leq 0.005)$ by $3 \mathrm{NOP}$ compared with the control. Concentration of ammonia in ruminal fluid was decreased $(P<0.02)$ and that of dissolved $\mathrm{H}_{2}$ appeared to be numerically increased $(P=0.27)$ by 3 NOP. Methanogen and bacterial cell counts in whole ruminal contents were not different $(P$ $\geq 0.19$ ) between treatments but as proportion of the total counts, bacteria tended to be increased $(P=0.10)$ and methanogens to be decreased $(P=0.07)$ by 3 NOP.
Table 2. Effect of 3-nitrooxypropanol (3NOP) on carbon dioxide $\left(\mathrm{CO}_{2}\right)$, methane $\left(\mathrm{CH}_{4}\right)$, and hydrogen $\left(\mathrm{H}_{2}\right)$ emissions in lactating dairy cows

\begin{tabular}{|c|c|c|c|c|}
\hline \multirow{2}{*}{ Item } & \multicolumn{2}{|c|}{ Treatment $^{1}$} & \multirow[b]{2}{*}{$\mathrm{SEM}^{2}$} & \multirow[b]{2}{*}{$P$-value } \\
\hline & $\mathrm{CON}$ & $3 \mathrm{NOP}$ & & \\
\hline $\mathrm{CO}_{2}, \mathrm{~g} / \mathrm{d}$ & 14,303 & 14,905 & 623.5 & 0.15 \\
\hline $\mathrm{CH}_{4}, \mathrm{~g} / \mathrm{d}$ & 487 & 335 & 40.1 & $<0.001$ \\
\hline $\mathrm{CH}_{4}, \mathrm{~g} / \mathrm{kg}$ of $\mathrm{DMI}^{3}$ & 20.7 & 13.6 & 1.40 & $<0.001$ \\
\hline $\mathrm{CH}_{4}, \mathrm{~g} / \mathrm{kg}$ of $\mathrm{milk}^{3}$ & 18.0 & 11.9 & 2.35 & $<0.001$ \\
\hline $\mathrm{H}_{2}, \mathrm{~g} / \mathrm{d}$ & $0.0^{4}$ & 1.3 & 0.13 & $<0.001$ \\
\hline
\end{tabular}

${ }^{1}$ Treatments were control $(\mathrm{CON})$, and $60 \mathrm{mg}$ of $3 \mathrm{NOP} / \mathrm{kg}$ of feed $\mathrm{DM}$ (3NOP).

${ }^{2}$ Largest SEM published in table; $\mathrm{n}=61$ for all variables ( $\mathrm{n}$ represents the number of observations used in the statistical analysis).

${ }^{3}$ Based on milk yield and DMI data during the gas measurement periods.

${ }^{4} 0.005 \mathrm{~g} / \mathrm{d}$.

Similar to our results, both Haisan et al. (2014) and Reynolds et al. (2014) observed a decrease in acetate concentration and acetate-to-propionate ratio when cows were supplemented with $3 \mathrm{NOP}$. Reynolds et al. (2014) observed also increased propionate concentration and a tendency for decreased rumen $\mathrm{pH}$ when cows were fed $500 \mathrm{mg}$ of $3 \mathrm{NOP} / \mathrm{d}$ and reported increased butyrate concentration with the 2,500-mg of $3 \mathrm{NOP} / \mathrm{d}$ dose. In contrast with our data, however, Reynolds et al. (2014) reported decreased isovalerate concentration, but this pattern was not observed in beef steers (Romero-Pérez et al., 2014, 2015a). Propionate production is a competitive mechanism to remove excess $\mathrm{H}_{2}$ in the rumen (Ellis et al., 2008; McAllister and Newbold, 2008). Considering that $3 \mathrm{NOP}$ decreased $\mathrm{CH}_{4}$ emission and the incomplete recovery of reducing equivalents in emitted $\mathrm{H}_{2}$, the observed increase in molar proportion of propionate and the decrease in acetate in this study was expected. A decrease in rumen ammonia concentration with $3 \mathrm{NOP}$ was also reported by Reynolds et al. (2014) for dairy cows, but not in the experiments with beef cattle by Romero-Pérez et al. (2014, 2015a). Decreased ammonia concentration in the rumen may be an indication of decreased proteolysis or increased ammonia uptake by the rumen bacteria. Urinary N excretion and MUN concentration (similar to the current data) were not affected by $3 \mathrm{NOP}$ in our larger experiment (unpublished data from Hristov et al., 2015a).

The dissolved $\mathrm{H}_{2}$ data were extremely variable (Table 3 ) in this experiment and, similar to the isotope data (discussed below), were obtained during experimental period 2 only. Concentration of dissolved $\mathrm{H}_{2}$ in rumen fluid did not differ $(P=0.27)$ between control and 3NOP. Hydrogen is an important intermediate in $\mathrm{CH}_{4}$ formation in the rumen and concentration of dissolved 
Table 3. Effect of 3-nitrooxypropanol (3NOP) on rumen fluid pH, VFA, ammonia, and dissolved hydrogen concentrations, and rumen bacteria and methanogens in lactating dairy cows

\begin{tabular}{|c|c|c|c|c|}
\hline \multirow[b]{2}{*}{ Item } & \multicolumn{2}{|c|}{ Treatment $^{1}$} & \multirow[b]{2}{*}{$\mathrm{SEM}^{2}$} & \multirow[b]{2}{*}{$P$-value ${ }^{3}$} \\
\hline & $\mathrm{CON}$ & $3 \mathrm{NOP}$ & & \\
\hline $\mathrm{pH}$ & 6.35 & 6.41 & 0.082 & 0.66 \\
\hline Total VFA, mmol/L & 90.0 & 85.8 & 2.96 & 0.43 \\
\hline Acetate & 59.1 & 52.9 & 2.18 & 0.08 \\
\hline Propionate & 17.4 & 17.4 & 1.30 & 0.99 \\
\hline Butyrate & 10.1 & 11.3 & 0.43 & 0.08 \\
\hline Isobutyrate & 0.51 & 0.49 & 0.049 & 0.51 \\
\hline Valerate & 1.91 & 1.96 & 0.073 & 0.66 \\
\hline Isovalerate & 1.01 & 1.76 & 0.147 & $<0.01$ \\
\hline Acetate-to-propionate ratio & 3.51 & 3.12 & 0.277 & $<0.01$ \\
\hline \multicolumn{5}{|l|}{ Molar proportions, $\%$} \\
\hline Acetate & 65.7 & 61.7 & 1.24 & $<0.001$ \\
\hline Propionate & 19.3 & 20.3 & 1.38 & 0.03 \\
\hline Butyrate & 11.1 & 13.1 & 0.33 & $<0.001$ \\
\hline Isobutyrate & 0.57 & 0.57 & 0.054 & 0.95 \\
\hline Valerate & 2.12 & 2.29 & 0.071 & 0.005 \\
\hline Isovalerate & 1.12 & 2.05 & 0.157 & $<0.001$ \\
\hline Ammonia, mmol/L & 2.93 & 1.94 & 0.404 & 0.02 \\
\hline Dissolved hydrogen, mg/L & 0.2 & 1.2 & 0.55 & 0.27 \\
\hline \multicolumn{5}{|l|}{ Bacteria } \\
\hline $\mathrm{ECC}^{4} \times 10^{6} / \mathrm{g}$ of ruminal contents & 10.6 & 11.5 & 0.78 & 0.45 \\
\hline$\%$ of total counts & 98.8 & 99.2 & 0.19 & 0.10 \\
\hline \multicolumn{5}{|l|}{ Methanogens } \\
\hline ECC,$\times 10^{6} / \mathrm{g}$ of ruminal contents & 0.13 & 0.09 & 0.018 & 0.19 \\
\hline$\%$ of total counts & 1.16 & 0.77 & 0.18 & 0.07 \\
\hline
\end{tabular}

$\mathrm{H}_{2}$ has been suggested as limiting methanogenesis (Hungate, 1967). Due to its rapid metabolism, however, $\mathrm{H}_{2}$ does not accumulate in the rumen liquid phase. Robinson et al. (1981), for example, observed a rapid increase in dissolved $\mathrm{H}_{2}$ concentration in the rumen of a cow $1 \mathrm{~h}$ after feeding, reaching $15 \mu \mathrm{mol} / \mathrm{L}$, and then declining to about $3 \mu \mathrm{mol} / \mathrm{L}$ at $4 \mathrm{~h}$ after feeding. Similar dissolved $\mathrm{H}_{2}$ concentration pattern after feeding was reported earlier by Czerkawski and Breckenridge (1971). Hegarty and Gerdes (1999) estimated that less than $0.1 \%$ of the $\mathrm{H}_{2}$ in the rumen of a sheep was $\mathrm{H}_{2}$ gas, with $92 \%$ being in water, $6 \%$ in feed, and $2 \%$ in the rumen microbes. Hydrogen balance in the rumen is highly dynamic and the low dissolved $\mathrm{H}_{2}$ concentrations observed in the current experiment are in line with other published data. Although dissolved $\mathrm{H}_{2}$ concentrations correlate poorly to $\mathrm{H}_{2}$ concentration in the rumen gas space (Hegarty and Gerdes, 1999; Wang et al., 2014), the increased $\mathrm{H}_{2}$ emission and the numerical trend for increased dissolved $\mathrm{H}_{2}$ in the current experiment suggest increased $\mathrm{H}_{2}$ accumulation in the rumen of the 3NOP-treated cows. This increase was accompanied with a shift in relative VFA concentrations, as would be expected based on rumen stoichiometry (Wolin, 1960;
Hegarty and Gerdes, 1999). In a recent meta-analysis of in vitro data, rumen stoichiometry could not completely explain $\mathrm{H}_{2}$ balance when methanogenesis was inhibited, and it was suggested that $\mathrm{H}_{2}$ may have been increasingly incorporated into formate, microbial biomass, or reductive acetogenesis (Ungerfeld, 2015).

There was no difference in $\delta \mathrm{D}_{\mathrm{CH} 4}$ and $\Delta^{13} \mathrm{CH}_{3} \mathrm{D}$, but a trend for decreased $(P=0.08) \delta^{13} \mathrm{C}_{\mathrm{CH} 4}$ was observed for $3 \mathrm{NOP}$ compared with the control (Table 4). Isotope compositions of $\mathrm{CH}_{4}$, similar to other fractionation processes in nature, reflect the source substrate as well as isotope fractionation associated with microbial methanogenesis. As an example, ammonia $\mathrm{N}$ volatilized from manure is highly depleted in the heavier isotope of $\mathrm{N},{ }^{15} \mathrm{~N}$, and the resulting manure becomes increasingly enriched in ${ }^{15} \mathrm{~N}$ as ammonia is being emitted. These relationships were used to model and predict ammonia losses from manure (Hristov et al., 2006, 2009). Similarly, microbial $\mathrm{CH}_{4}$ formation produces $\mathrm{CH}_{4}$ that is relatively depleted in ${ }^{13} \mathrm{C}$ and $\mathrm{D}$ compared with source $\mathrm{CO}_{2}$ (or acetate) and water, therefore more negative $\delta^{13} \mathrm{C}_{\mathrm{CH} 4}$ and $\delta \mathrm{D}_{\mathrm{CH} 4}$ values (Whiticar, 1999). The source of carbon and $\mathrm{H}_{2}$, metabolic substrate, and methanogenesis pathway influence the composition of conven- 
tional isotopes of $\mathrm{CH}_{4}$ (Valentine et al., 2004; Conrad, 2005). Moreover, growth phase and availability of environmental $\mathrm{H}_{2}$ may affect the isotopologue compositions of $\mathrm{CH}_{4}$ (Burke, 1993; Valentine et al., 2004; Wang et al., 2015). Therefore, in the current study we hypothesized that if the rumen archaeal population shifts due to effects associated with the addition of $3 \mathrm{NOP}$, such as the inhibition of methyl coenzyme-M reductase, we may see a shift in the isotopic composition of $\mathrm{CH}_{4}$. According to Vogel (1980), $\delta^{13} \mathrm{C}_{\mathrm{CH} 4}$ of enteric $\mathrm{CH}_{4}$ is strongly dependent on $\delta^{13} \mathrm{C}$ of the feeds in the diet. Rust (1981) evaluated the isotopic composition of $\mathrm{CH}_{4}$ in steers, dairy cows, and wethers fed diets that were mostly based on $\mathrm{C}_{3}$ (alfalfa, soybean, and temperate grass species) or $\mathrm{C}_{4}$ (corn-based diets) plants. That study reported that $\delta^{13} \mathrm{C}_{\mathrm{CH} 4}$ of ruminants fed $\mathrm{C}_{3}$-based diets averaged $-63.7 \%$, whereas animals fed $\mathrm{C}_{4}$-based diets averaged $-50.3 \%$. Levin et al. (1993) investigated the isotopic composition of enteric $\mathrm{CH}_{4}$ and different sources of dairy wastes (liquid manure, biogas) and reported $\delta^{13} \mathrm{C}_{\mathrm{CH} 4}$ values for enteric $\mathrm{CH}_{4}$ of $-65.1 \%$ for cows fed $100 \% \mathrm{C}_{3}$ diets and $-55.6 \%$ when cows were fed 60 to $80 \% \mathrm{C}_{4}$ diets. These differences are explained by the carbon isotope compositions of feeds, as $\mathrm{C}_{3}$ plants produces larger ${ }^{13} \mathrm{C} /{ }^{12} \mathrm{C}$ fractionations compared with $\mathrm{C}_{4}$ plants (e.g., Farquhar et al., 1989).

In a recent work by Wang et al. (2015), the $\delta^{13} \mathrm{C}_{\mathrm{CH} 4}$ of rumen $\mathrm{CH}_{4}$ from dairy cows (of the Pennsylvania State University herd) ranged from -52 to $-54 \%$. The $\delta^{13} \mathrm{C}_{\mathrm{CH} 4}$ values reported in our study for the control group (average of $-54 \%$ ) are similar to those reported in Wang et al. (2015). The $\delta^{13} \mathrm{C}_{\mathrm{CH} 4}$ values for the 3 NOP group were slightly $(4 \%)$ more depleted in ${ }^{13} \mathrm{C}$. Although $\delta^{13} \mathrm{C}$ value of the feeds were not measured, the same feeds were used for both $3 \mathrm{NOP}$ and control. Given the range observed by Vogel (1980) of $13.4 \%$ for source variation, the observed shift $\delta^{13} \mathrm{C}_{\mathrm{CH} 4}$ of $4 \%$ would require major changes in feed composition. Therefore, the change in $\delta^{13} \mathrm{C}_{\mathrm{CH} 4}$ value likely reflects the change in physiology of methanogens and is consistent with low methanogenesis rate under $3 \mathrm{NOP}$ treatment, as large ${ }^{13} \mathrm{C}$-depletion is associated with low methanogenesis rates under stationary phase cultures (Botz et al., 1996; Zyakun, 1996).

Although it was not sampled at the same time, previous analysis of water in rumen yielded $\delta \mathrm{D}$ value of $-32 \%$ (supplementary material, Table S4 of Wang et al., 2015). Although it was hypothesized that environmental $\mathrm{H}_{2}$ levels affect $\delta \mathrm{D}_{\mathrm{CH} 4}$ and $\Delta^{13} \mathrm{CH}_{3} \mathrm{D}$ values (Burke, 1993; Wang et al., 2015), we did not observe changes in the values of $\delta \mathrm{D}_{\mathrm{CH} 4}$ and $\Delta^{13} \mathrm{CH}_{3} \mathrm{D}$.

Genus distribution of methanogenic archaea (Methanobrevibacter, Methanosphaera, and Methanomicrobium
Table 4. Effect of 3-nitrooxypropanol (3NOP) on isotopic composition of enteric methane in lactating dairy cows

\begin{tabular}{|c|c|c|c|c|}
\hline \multirow[b]{2}{*}{ Item } & \multicolumn{2}{|c|}{ Treatment $^{1}$} & \multirow[b]{2}{*}{$\mathrm{SEM}^{2}$} & \multirow[b]{2}{*}{$P$-value } \\
\hline & $\mathrm{CON}$ & $3 \mathrm{NOP}$ & & \\
\hline $\begin{array}{l}\delta^{13} \mathrm{C}_{\mathrm{CH} 4}, \% \\
\delta \mathrm{D}_{\mathrm{CH} 4}, \% \\
\Delta^{13} \mathrm{CH}_{3} \mathrm{D}, \%\end{array}$ & $\begin{array}{r}-54.5 \\
-347.4 \\
1.66\end{array}$ & $\begin{array}{r}-58.3 \\
-347.4 \\
1.41\end{array}$ & $\begin{array}{l}1.14 \\
1.79 \\
1.063^{3}\end{array}$ & $\begin{array}{l}0.08 \\
0.99 \\
0.87\end{array}$ \\
\hline
\end{tabular}

${ }^{1}$ Treatments were control $(\mathrm{CON})$, and $60 \mathrm{mg}$ of $3 \mathrm{NOP} / \mathrm{kg}$ of feed $\mathrm{DM}$ (3NOP).

${ }^{2}$ Largest SEM published in table; $\mathrm{n}=6$ for all variables ( $\mathrm{n}$ represents the number of observations used in the statistical analysis). Values for $\delta^{13} \mathrm{C}, \delta \mathrm{D}$, and $\Delta^{13} \mathrm{CH}_{3} \mathrm{D}$, where $\mathrm{D}$ is deuterium, are reported relative to Pee Dee Belemnite (PDB), Standard Mean Ocean Water (SMOW), and the stochastic distribution, respectively as described in Wang et al. (2015).

${ }^{3}$ Large SEM caused by small sample size of 2 of the 3 NOP samples.

spp.) in whole ruminal contents was not affected $(P$ $>0.44$ ) by $3 \mathrm{NOP}$ (Table 5). Methanobrevibacter spp. was the dominant archaea genus, which was in agreement with methanogens distribution in the rumen of lactating dairy cows fed TMR diets (Whitford et al., 2001). Similar to our data, both Haisan et al. (2014) and Romero-Pérez et al. (2015a) reported a decreased number of methanogens when dairy or beef cattle were treated with 3NOP. In the current study, the predominant bacterial orders were Clostridiales and Bacteroidales. Clostridiales tended to be decreased $(P=0.09)$, whereas both Selenomonadales and Fibrobacterales were increased ( $P=0.04$, and 0.02 , respectively) by 3 NOP. Prevotella spp., the predominant bacterial genus in ruminal contents, was not affected by 3 NOP. Ruminococcus, Succiniclasticum, Clostridium, and Sarcina spp. were decreased $(P \leq 0.03)$, whereas Butyrivibrio and Fibrobacter spp. were increased $(P=0.01)$ by $3 \mathrm{NOP}$ compared with the control. Data on the effect of $3 \mathrm{NOP}$ on rumen microbial diversity are generally lacking or are inconsistent. Haisan et al. (2014), for example, reported a trend for decreased total bacterial $16 \mathrm{~S}$ rDNA gene copy numbers and no effect on protozoal (18S rRNA) copy numbers in ruminal contents from 3NOPtreated cows. Romero-Pérez et al. (2015a) observed no effect of $3 \mathrm{NOP}$ on bacterial gene copy numbers but a large increase in protozoal copy numbers in beef cattle, whereas in another study from the same group, no effect was observed on both bacterial and protozoal copy numbers (Romero-Pérez et al., 2014). In yet another study by Romero-Pérez et al. (2015b) using the rumen stimulation technique RUSITEC, the total copy number of $16 \mathrm{~S}$ rRNA genes for methanogens and bacteria in the liquid phase were not affected by $3 \mathrm{NOP}$, but there was a large decrease in the solid associated methanogens. Likewise, no effect of $3 \mathrm{NOP}$ on rumen protozoal counts 
Table 5. Effect of 3-nitrooxypropanol (3NOP) on bacterial and archaeal order and genus composition (as $\%$ of total sequence reads ${ }^{1}$ ) in whole ruminal contents of lactating dairy cows

\begin{tabular}{|c|c|c|c|c|}
\hline \multirow[b]{2}{*}{ Item } & \multicolumn{2}{|c|}{ Treatment $^{2}$} & \multirow[b]{2}{*}{$\mathrm{SEM}^{3}$} & \multirow[b]{2}{*}{$P$-value } \\
\hline & $\mathrm{CON}$ & $3 \mathrm{NOP}$ & & \\
\hline \multicolumn{5}{|l|}{ Archaeal genus } \\
\hline Methanobrevibacter & 94.9 & 95.0 & 1.03 & 0.87 \\
\hline Methanosphaera & 3.8 & 3.8 & 1.01 & 0.98 \\
\hline Methanomicrobium & 1.2 & 0.8 & 0.39 & 0.44 \\
\hline \multicolumn{5}{|l|}{ Bacterial order } \\
\hline Clostridiales & 48.8 & 43.5 & 2.76 & 0.09 \\
\hline Bacteroidales & 32.6 & 34.9 & 1.84 & 0.32 \\
\hline Selenomonadales & 7.1 & 8.7 & 1.41 & 0.04 \\
\hline Fibrobacterales & 1.3 & 2.5 & 0.32 & 0.02 \\
\hline Bifidobacteriales & 1.8 & 1.8 & 0.52 & 0.86 \\
\hline Lactobacillales & 1.2 & 1.7 & 0.29 & 0.25 \\
\hline Rhodocyclales & 1.1 & 1.1 & 0.09 & 0.85 \\
\hline Actinomycetales & 0.9 & 1.2 & 0.16 & 0.10 \\
\hline \multicolumn{5}{|l|}{ Bacterial genus } \\
\hline Prevotella & 22.0 & 23.2 & 1.62 & 0.55 \\
\hline Ruminococcus & 8.2 & 6.5 & 0.62 & $<0.01$ \\
\hline Succiniclasticum & 8.1 & 6.6 & 1.34 & 0.03 \\
\hline Blautia & 5.1 & 5.4 & 0.34 & 0.45 \\
\hline Clostridium & 6.2 & 4.1 & 0.49 & 0.03 \\
\hline Butyrivibrio & 3.6 & 4.8 & 0.33 & 0.01 \\
\hline Barnesiella & 3.8 & 4.0 & 0.29 & 0.31 \\
\hline Pseudobutyrivibrio & 3.2 & 3.1 & 0.18 & 0.57 \\
\hline Acetitomaculum & 3.5 & 2.6 & 0.39 & 0.05 \\
\hline Alistipes & 2.6 & 3.3 & 0.39 & 0.31 \\
\hline Coprococcus & 2.8 & 2.4 & 0.37 & 0.28 \\
\hline Dorea & 2.3 & 1.9 & 0.37 & 0.44 \\
\hline Sarcina & 2.6 & 1.5 & 0.24 & 0.02 \\
\hline Fibrobacter & 1.3 & 2.5 & 0.32 & 0.02 \\
\hline Bacteroides & 1.8 & 1.9 & 0.12 & 0.45 \\
\hline Saccharofermentans & 1.9 & 1.7 & 0.34 & 0.47 \\
\hline Bifidobacterium & 1.7 & 1.8 & 0.56 & 0.96 \\
\hline Flavonifractor & 1.6 & 1.8 & 0.19 & 0.35 \\
\hline Xylanibacter & 1.1 & 1.2 & 0.13 & 0.56 \\
\hline Roseburia & 1.1 & 1.2 & 0.13 & 0.64 \\
\hline Azospira & 1.2 & 1.1 & 0.09 & 0.85 \\
\hline Streptococcus & 0.9 & 1.1 & 0.11 & 0.38 \\
\hline
\end{tabular}

${ }^{1}$ The percentage represents the percentage of the total sequences analyzed within the sample.

${ }^{2}$ Treatments were control $(\mathrm{CON})$, and $60 \mathrm{mg}$ of $3 \mathrm{NOP} / \mathrm{kg}$ of feed DM (3NOP).

${ }^{3}$ Largest SEM published in table; $\mathrm{n}=12$ for all variables ( $\mathrm{n}$ represents the number of observations used in the statistical analysis).

was noted in that study. No effect of $3 \mathrm{NOP}$ on bacterial and protozoal (as well as methanogenic archaea) gene copy numbers was also reported by Martínez-Fernández et al. (2014) in sheep. The distinct decrease in fibrolytic bacteria such as Ruminococcus spp. in the current study is in line with the decreased acetate concentration (and molar proportion) in ruminal fluid with 3NOP. Similarly, the increase in Butyrivibrio spp. is in agreement with the trend for increased butyrate concertation and molar proportion with 3NOP. The increase in Selenomonadales, an order that includes major propionateproducing bacteria such as Selenomonas ruminantium (Paynter and Elsden, 1970), is in agreement with the
Table 6. Effect of 3-nitrooxypropanol (3NOP) on DMI, milk production, and feed efficiency in lactating dairy cows

\begin{tabular}{|c|c|c|c|c|}
\hline \multirow[b]{2}{*}{ Item } & \multicolumn{2}{|c|}{ Treatment $^{1}$} & \multirow[b]{2}{*}{$\mathrm{SEM}^{2}$} & \multirow[b]{2}{*}{$P$-value } \\
\hline & $\mathrm{CON}$ & $3 \mathrm{NOP}$ & & \\
\hline $\mathrm{DMI}, \mathrm{kg} / \mathrm{d}$ & 24.1 & 24.8 & 0.88 & 0.37 \\
\hline Milk yield, $\mathrm{kg} / \mathrm{d}$ & 28.2 & 30.3 & 2.63 & 0.27 \\
\hline $\mathrm{ECM},{ }^{3} \mathrm{~kg} / \mathrm{d}$ & 32.9 & 32.0 & 2.57 & 0.87 \\
\hline Feed efficiency, ${ }^{4} \mathrm{~kg} / \mathrm{kg}$ & 1.18 & 1.22 & 0.102 & 0.53 \\
\hline Milk fat, \% & 4.05 & 4.35 & 0.27 & 0.05 \\
\hline Milk fat, $\mathrm{kg} / \mathrm{d}$ & 1.13 & 1.32 & 0.10 & 0.08 \\
\hline Milk protein, \% & 3.56 & 3.58 & 0.13 & 0.80 \\
\hline Milk protein $\mathrm{kg} / \mathrm{d}$ & 1.02 & 1.10 & 0.10 & 0.40 \\
\hline Milk lactose, $\%$ & 4.74 & 4.73 & 0.12 & 0.80 \\
\hline Milk lactose, $\mathrm{kg} / \mathrm{d}$ & 1.33 & 1.46 & 0.15 & 0.17 \\
\hline MUN, mg/dL & 11.7 & 11.1 & 0.77 & 0.29 \\
\hline
\end{tabular}

${ }^{1}$ Treatments were control $(\mathrm{CON})$, and $60 \mathrm{mg}$ of $3 \mathrm{NOP} / \mathrm{kg}$ of feed DM (3NOP).

${ }^{2}$ Largest SEM published in table; $\mathrm{n}=11$ for all other variables ( $\mathrm{n}$ represents the number of observations used in the statistical analysis). Data for one cow in period 2 (control) were removed from the analysis due to low milk production (see Materials and Methods).

${ }^{3}$ Energy-corrected milk calculated as $\mathrm{ECM}(\mathrm{kg})=$ milk production $(\mathrm{kg}) \times(383 \times$ fat $\%+242 \times$ protein $\%+165.4 \times$ lactose $\%+20.7)$ $\div 3,140$ (Sjaunja et al., 1990).

${ }^{4}$ Milk yield $\div$ DMI.

increased relative proportion of propionate in ruminal VFA. The prevalence of specific genera within this order, however (e.g., Succiniclasticum spp., bacteria converting succinate to propionate; van Gylswyk, 1995), was lowered by 3 NOP. Some rumen clostridia have strong proteolytic and deaminative (Paster et al., 1993; Krause and Russell, 1996) activities (McSweeney et al., 1999), and the decrease in Clostridium spp. with 3NOP in the current experiment is in line with the observed decrease in rumen ammonia concentration.

Dry matter intake and milk yield were not different between 3NOP and the control (Table 6). Energycorrected milk yield and feed efficiency were also not affected by treatment. Milk fat concentration was increased $(P=0.05)$ and milk fat yield tended to be increased $(P=0.08)$ by $3 \mathrm{NOP}$ compared with the control. A numerical increase in milk fat concentration with 3NOP was also reported by Haisan et al. (2014) and may be reflective of increased feed energy availability due to decreased $\mathrm{CH}_{4}$ production. Milk protein and lactose concentrations and yields and MUN were not affected by treatment in the current experiment. The lack of effect of $3 \mathrm{NOP}$ on milk yield in the current experiment is in agreement with data from our larger production experiment (Hristov et al., 2015a) and other published studies (Haisan et al., 2014; Reynolds et al., 2014). Production data from the current experiment, however, should be interpreted with caution due to the low number of experimental units and the advanced DIM of the cows. 


\section{CONCLUSIONS}

The $\mathrm{CH}_{4}$ inhibitor tested in this experiment, 3-nitrooxypropanol, decreased enteric $\mathrm{CH}_{4}$ emission by $31 \%$ and decreased acetate-to-propionate ratio, increased molar proportions of propionate and butyrate, and decreased ammonia concentration in ruminal fluid of lactating dairy cows. The inhibitor had no effect on rumen archaea composition, but tended to decrease the proportion of methanogen cell counts in whole ruminal contents. In line with the lack of effect on rumen archaeal genus distribution, the isotopic composition of $\mathrm{CH}_{4}$ was similar between treatments.

\section{ACKNOWLEDGMENTS}

The authors thank the staff of the Department of Animal Science, Pennsylvania State University's Dairy Center for their conscientious care of the experimental cows. The study was partially funded by DSM Nutritional Products. Danielle Sarah Gruen was supported by Royal Dutch Shell (The Hague, the Netherlands)Massachusetts Institute of Technology Energy Initiative graduate fellowship. J. C. Lopes was supported by CAPES Foundation, Ministry of Education of Brazil (Brasília, Brazil).

\section{REFERENCES}

Abecia, L., P. G. Toral, A. I. Martín-García, G. Martínez, N. W. Tomkins, E. Molina-Alcaide, C. J. Newbold, and D. R. Yáñez-Ruiz. 2012. Effect of bromochloromethane on methane emission, rumen fermentation pattern, milk yield, and fatty acid profile in lactating dairy goats. J. Dairy Sci. 95:2027-2036.

Boadi, D., C. Benchaar, and J. Chiquette. 2004. Mitigation strategies to reduce enteric methane emissions from dairy cows: Update review. Can. J. Anim. Sci. 84:319-335.

Botz, R., H.-D. Pokojski, M. Schmitt, and M. Thomm. 1996. Carbon isotope fractionation during bacterial methanogenesis by $\mathrm{CO}_{2}$ reduction. Org. Geochem. 25:255-262.

Burke, R. A. 1993. Possible influence of hydrogen concentration on microbial methane stable hydrogen isotopic composition. Chemosphere 26:55-67.

Chapelle, F. H., D. A. Vroblesky, J. C. Woodward, and D. R. Lovely. 1997. Practical considerations for measuring hydrogen concentrations in groundwater. Environ. Sci. Technol. 31:2873-2877.

Conrad, R. 2005. Quantification of methanogenic pathways using stable carbon isotopic signatures: A review and a proposal. Org. Geochem. 36:739-752.

CVAS (Cumberland Valley Analytical Services). 2014. Resources-Lab Procedures. Accessed Nov. 23, 2015. http://www.foragelab.com/ Resources/Lab-Procedures/.

Czerkawski, J. W., and G. Breckenridge. 1971. Determination of concentration of hydrogen and some other gases dissolved in biological fluids. Lab. Pract. 20:403-405., 413.

Duval, S., and M. Kindermann. 2012. Use of nitrooxy organic molecules in feed for reducing enteric methane emissions in ruminants, and/or to improve ruminant performance. World Intellectual Property Organization. International Patent Application WO 2012/084629 A1.

Ellis, J. L., J. Dijkstra, E. Kebread, A. Bannink, N. E. Odongo, B. W. McBride, and J. France. 2008. Aspects of rumen microbiology central to mechanistic modelling of methane production in cattle. J. Agric. Sci. 146:213-233.

Ermler, U., W. Grabarse, S. Shima, M. Goubeaud, and R. K. Thauer. 1997. Crystal structure of methyl-coenzyme M reductase: The key enzyme of biological methane formation. Science 278:1457-1462.

Farquhar, G. D., J. R. Ehleringer, and K. T. Hubick. 1989. Carbon isotope discrimination and photosynthesis. Annu. Rev. Plant Physiol. Plant Mol. Biol. 40:503-537.

Goel, G., H. P. S. Makkar, and K. Becker. 2009. Inhibition of methanogens by bromochloromethane: Effects on microbial communities and rumen fermentation using batch and continuous fermentations. Br. J. Nutr. 101:1484-1492.

Haisan, J., Y. Sun, L. L. Guan, K. A. Beauchemin, A. Iwaasa, S. Duval, D. R. Barreda, and M. Oba. 2014. The effects of feeding 3-nitrooxypropanol on methane emissions and productivity of Holstein cows in mid lactation. J. Dairy Sci. 97:3110-3119.

Hegarty, R. S., and R. Gerdes. 1999. Hydrogen production and transfer in the rumen. Rec. Adv. Anim. Nutr. Austr. 12:37-44.

Hristov, A. N., L. Campbell, and J. H. Harrison. 2006. Evolution of ${ }^{15} \mathrm{~N}$ abundance in cattle manure in relation to cumulative ammonia losses. J. Dairy Sci. 89:357. (Abstr.).

Hristov, A. N., C. Lee, T. Cassidy, M. Long, K. Heyler, B. Corl, and R. Forster. 2011. Effects of lauric and myristic acids on ruminal fermentation, production, and milk fatty acid composition in lactating dairy cows. J. Dairy Sci. 94:382-395.

Hristov, A. N., J. Oh, F. Giallongo, T. Frederick, H. Weeks, P. R. Zimmerman, R. A. Hristova, S. R. Zimmerman, and A. F. Branco. 2015b. The use of an automated system (GreenFeed) to monitor enteric methane and carbon dioxide emissions from ruminant animals. J. Vis. Exp. 103:e52904.

Hristov, A. N., J. Oh, F. Giallongo, T. W. Frederick, M. T. Harper, H. L. Weeks, A. F. Branco, P. J. Moate, M. H. Deighton, S. R. O. Williams, M. Kindermann, and S. Duval. 2015a. An inhibitor persistently decreased enteric methane emission from dairy cows with no negative effect on milk production. Proc. Natl. Acad. Sci. USA 112:10663-10668.

Hristov, A. N., J. Oh, C. Lee, R. Meinen, F. Montes, T. Ott, J. Firkins, A. Rotz, C. Dell, A. Adesogan, W. Yang, J. Tricarico, E. Kebreab, G. Waghorn, J. Dijkstra, and S. Oosting. 2013. Mitigation of greenhouse gas emissions in livestock production- $\mathrm{A}$ review of technical options for non-CO2 emissions. P. J. Gerber, B. Henderson, and H. P. S. Makkar, ed. FAO Animal Production and Health Paper No. 177. FAO, Rome, Italy.

Hristov, A. N., S. Zaman, M. Vander Pol, L. Campbell, P. Ndegwa, and S. Silva. 2009. Nitrogen losses from dairy manure estimated through nitrogen mass balance or using markers. J. Environ. Qual. 38:2438-2448.

Hungate, R. E. 1966. The Rumen and its Microbes. Academic Press, New York, NY.

Hungate, R. E. 1967. Hydrogen as an intermediate in the rumen fermentation. Arch. Mikrobiol. 59:158-164.

IPCC. 2014. Climate change 2014: Impacts, adaptation, and vulnerability. Contribution of Working Group II to the Fifth Assessment Report of the Intergovernmental Panel on Climate Change. Cambridge Univ Press, Cambridge, UK.

Johnson, K. A., and D. E. Johnson. 1995. Methane emissions from cattle methane emissions from cattle. J. Anim. Sci. 73:2483-2492.

Krause, D. O., and J. B. Russell. 1996. An rRNA approach for assessing the role of obligate amino acid-fermenting bacteria in ruminal amino acid deamination. Appl. Environ. Microbiol. 62:815-821.

Levin, I., P. Bergamaschi, H. Dörr, and D. Trapp. 1993. Stable isotopic signature of methane from major sources in Germany. Chemosphere 26:161-177.

Martínez-Fernández, G., L. Abecia, A. Arco, G. Cantalapiedra-Hijar, A. I. Martín-García, E. Molina-Alcaide, M. Kindermann, S. Duval, and D. R. Yáñez-Ruiz. 2014. Effects of ethyl-3-nitrooxy propionate and 3-nitrooxypropanol on ruminal fermentation, microbial abundance, and methane emissions in sheep. J. Dairy Sci. 97:3790-3799.

McAllister, T. A., and C. J. Newbold. 2008. Redirecting rumen fermentation to reduce methanogenesis. Aust. J. Exp. Agric. 48:7-13. 
McSweeney, C. S., B. Palmer, R. Bunch, and D. O. Krause. 1999. Isolation and characterization of proteolytic ruminal bacteria from sheep and goats fed the tannin-containing shrub legume Calliandra calothyrsus. Appl. Environ. Microbiol. 65:3075-3083.

Moss, A. R., J.-P. Jouany, and J. Newbold. 2000. Methane production by ruminants: Its contribution to global warming. Ann. Zootech. 49:231-253.

NRC. 2001. Nutrient Requirements of Dairy Cattle. 7th rev. ed. Natl Acad. Sci., Washington, DC.

Oh, J., F. Giallongo, T. Frederick, J. Pate, S. Walusimbi, R. J. Elias, E. H. Wall, D. Bravo, and A. N. Hristov. 2015. Effects of dietary Capsicum oleoresin on productivity and immune responses in lactating dairy cows. J. Dairy Sci. 98:6327-6339.

Ono, S., D. T. Wang, D. S. Gruen, B. Sherwood Lollar, M. S. Zahniser, B. J. McManus, and D. D. Nelson. 2014. Measurement of a doubly substituted methane isotopologue, ${ }^{13} \mathrm{CH}_{3} \mathrm{D}$, by tunable infrared laser direct absorption spectroscopy. Anal. Chem. 86:6487-6494.

Paster, B. J., J. B. Russell, C. M. J. Yang, J. M. Chow, C. R. Woese, and R. Tanner. 1993. Phylogeny of ammonia-producing ruminal bacteria, Peptostreptococcus anaerobius, Clostridium sticklandii, and Clostridium aminophilum sp. nov. Int. J. Syst. Bacteriol. 43:107-110.

Paynter, M. J. B., and S. R. Elsden. 1970. Mechanism of propionate formation by Selenomonas ruminantium, a rumen micro-organism. J. Gen. Microbiol. 61:1-7.

Reynolds, C. K., D. J. Humphries, P. Kirton, M. Kindermann, S. Duval, and W. Steinberg. 2014. Effects of 3-nitrooxypropanol on methane emission, digestion, and energy and nitrogen balance of lactating dairy cows. J. Dairy Sci. 97:3777-3789.

Robinson, J. A., R. F. Strayer, and J. M. Tuedje. 1981. Method for measuring dissolved hydrogen in anaerobic ecosystems: Application to the rumen. Appl. Environ. Microbiol. 41:545-548.

Romero-Pérez, A., E. K. Okine, S. M. McGinn, L. L. Guan, M. Oba, S. M. Duval, M. Kindermann, and K. A. Beauchemin. 2014. The potential of 3-nitrooxypropanol to lower enteric methane emissions from beef cattle. J. Anim. Sci. 92:4682-4693.

Romero-Pérez, A., E. K. Okine, S. M. McGinn, L. L. Guan, M. Oba, S. M. Duval, M. Kindermann, and K. A. Beauchemin. 2015a. Sustained reduction in methane production from long-term addition of 3-nitrooxypropanol to a beef cattle diet. J. Anim. Sci. 93:1780-1791.

Romero-Pérez, A., E. K. Okine, L. L. Guan, S. M. Duval, M. Kindermannd, and K. A. Beauchemina. 2015b. Effects of 3-nitrooxypropanol on methane production usingthe rumen simulation technique (Rusitec). Anim. Feed Sci. Technol. 209:98-109.

Rust, F. 1981. Ruminant methane delta $\left({ }^{13} \mathrm{C} /{ }^{12} \mathrm{C}\right)$ values: Relation to atmospheric methane. Science 211:1044-1046.

Sawyer, M. S., W. H. Hoover, and C. J. Sniffen. 1974. Effects of a ruminal methane inhibitor on growth and energy metabolism in the ovine. J. Anim. Sci. 38:908-914.

Sjaunja, L. O., L. Baevre, L. Junkkarinen, J. Pedersen, and J. Setälä. 1990. A Nordic proposal for an energy corrected milk (ECM) for- mula. Pages 156-157 in 27th Session of the International Commission for Breeding and Productivity of Milk Animals, Paris, France. Wageningen Academic Publishers, Wageningen, the Netherlands.

Tekippe, J. A., A. N. Hristov, K. S. Heyler, T. W. Cassidy, V. D. Zheljazkov, J. F. S. Ferreira, S. K. Karnati, and G. A. Varga. 2011. Rumen fermentation and production effects of Origanum vulgare L. leaves in lactating dairy cows. J. Dairy Sci. 94:5065-5079.

Tomkins, N. W., S. M. Colegate, and R. A. Hunter. 2009. A bromochloromethane formulation reduces enteric methanogenesis in cattle fed grain-based diets. Anim. Prod. Sci. 49:1053-1058.

Ungerfeld, E. M. 2015. Shifts in metabolic hydrogen sinks in the methanogenesis inhibited ruminal fermentation: A meta-analysis. Front. Microbiol. 6:37.

Valentine, D. L., A. Chidthaisong, A. Rice, W. S. Reeburgh, and S. C. Tyler. 2004. Carbon and hydrogen isotope fractionation by moderately thermophilic methanogens. Geochim. Cosmochim. Acta 68:1571-1590

van Gylswyk, N. O. 1995. Succiniclasticum ruminis gen. nov., sp. nov. a ruminal bacterium converting succinate to propionate as the sole energy-yielding mechanism. Int. J. Syst. Bacteriol. 45:297-300.

Vogel, J. C. 1980. Fractionation of the Carbon Isotopes During Photosynthesis. Springer, Berlin, Germany.

Wang, D. T., D. S. Gruen, B. S. Lollar, K.-U. Hinrichs, L. C. Stewart, J. F. Holden, A. N. Hristov, J. W. Pohlman, P. L. Morrill, M. Könneke, K. B. Delwiche, E. P. Reeves, C. N. Sutcliffe, D. J. Ritter, J. S. Seewald, J. C. McIntosh, H. F. Hemond, M. D. Kubo D. Cardace, T. M. Hoehler, and S. Ono. 2015. Methane cycling. Nonequilibrium clumped isotope signals in microbial methane. Science 348:428-431.

Wang, M., X. Z. Sun, P. H. Janssen, S. X. Tang, and Z. L. Tan. 2014. Responses of methane production and fermentation pathways to the increased dissolved hydrogen concentrationgenerated by eight substrates in in vitro ruminal cultures. Anim. Feed Sci. Technol. 194:1-11.

Whitford, M. F., R. M. Teather, and R. J. Forster. 2001. Phylogenetic analysis of methanogens from the bovine rumen. BMC Microbiol. $1: 5$

Whiticar, M. J. 1999. Carbon and hydrogen isotope systematics of bacterial formation and oxidation of methane. Chem. Geol 161:291-314.

Whiticar, M. J., E. Faber, and M. Schoell. 1986. Biogenic methane formation in marine and freshwater environments: $\mathrm{CO}_{2}$ reduction vs. acetate fermentation-Isotope evidence. Geochim. Cosmochim. Acta 50:693-709

Wolin, M. J. 1960. A theoretical rumen fermentation balance. J. Dairy Sci. 43:1452-1459.

Zyakun, A. M. 1996. Potential of ${ }^{13} \mathrm{C} /{ }^{12} \mathrm{C}$ variations in bacterial methane in assessing origin of environmental methane. Pages 341-352 in Hydrocarbon Migration and its Near-Surface Expression: AAPG Memoir 66D. D. Schumacher and M. A. Abrams, ed. The American Association of Petroleum Geologists, Tulsa, OK. 